\title{
Ultrastructural Studies of the Ovary of Palaeococcus fuscipennis (Burmeister) (Insecta, Hemiptera, Coccinea: Monophlebidae)*
}

\author{
Teresa SZKLARZEWICZ, Katarzyna KęDRA and Sylwia NiżNIK
}

Accepted January 25, 2005

\begin{abstract}
SZKLARZEWICZ T., KęDRA K., NiŻNIK S. 2005. Ultrastructural studies of the ovary of Palaeococcus fuscipennis (Burmeister) (Insecta, Hemiptera, Coccinea: Monophlebidae). Folia biol. (Kraków) 53: 45-50.

Ovaries of Palaeocoocus fuscipennis are composed of about 100 telotrophic ovarioles that are devoid of terminal filaments. In the ovariole a tropharium (=trophic chamber) and vitellarium can be distinguished. The tropharium contains 7 trophocytes. A single oocyte develops in the vitellarium. The oocyte is surrounded by follicular cells that do not undergo diversification into subpopulations. The obtained results are discussed in a phylogenetic context.

Key words: Oogenesis, ovariole, phylogeny, scale insects, ultrastructure.

Teresa SZKLARZEWICZ, Katarzyna KĘDRA, Sylwia NIŻNIK, Department of Systematic Zoology and Zoogeography, Institute of Zoology, Jagiellonian University, R. Ingardena 6, 30-060 Kraków, Poland.

E:mail:szkla@zuk.iz.uj.edu.pl
\end{abstract}

Scale insects (coccids, coccoids) are the most specialized hemipterans. In view of the fact that they are chararacterized by numerous synapomorphies, their monophyletic origin is widely accepted by entomologists (e.g., KOTEJA 1974 a, MiLler 1984, DANZIG 1986, FOLDI 1997, COOK et al. 2002). Scale insects are usually divided into two groups, the primitive Archaeococcoidea (=Orthezioidea) and advanced Neococcoidea (=Coccoidea s. str.) (BORCHSENIUS 1956, KOTEJA 1974a). Results of morphological as well as molecular studies indicate that neococcoids represent a monophyletic unit and comprise well defined families (Pseudococcidae, Kermesidae, Eriococcidae, Coccidae, Asterolecaniidae, Diaspididae and several small families) (KOTEJA 1974a, b, DANZIG 1986, CoOK et al. 2002). In contrast to advanced scale insects, archaeococcoids are characterized by plesiomorphic characters only (e.g., the presence of abdominal spiracles in all stages and compound eyes in males), therefore their monophyletic origin as well as classification are still under discussion (KOTEJA 1974a, GULLAN \& SJAARDA 2001, FOLDI 1997). It is interesting to note that results of recent molecular studies indicate that Archaeococcoidea may be a paraphyletic group (COOK et al. 2002). MORRISON (1928) classified primi- tive scale insects into two families, Ortheziidae and Margarodidae s. $l$. The latter has been subdivided into five subfamilies, i.e., the Margarodinae, Monophlebinae, Coelostomidiinae, Xylococcinae and Steingeliinae. While the monyphyly of the family Ortheziidae is well documented (KOTEJA 1974 a, GULLAN \& SJAARDA 2001, COOK et al. 2002), the monophyletic origin of the Margarodidae $s . l$. has not been proved (FOLDI 1997, COOK et al. 2002). KOTEJA (1974 a, b) on the basis of morphology of mouthparts elevated all five subfamilies and two tribes sensu MORRISON to family rank. Besides these groups, he included the small family Phenacoleachiidae into Archaeococcoidea. It should be noted that molecular records (COOK et al. 2002) and studies on ovaries (SZKLARZEWICZ 1998c, KOTEJA et al. 2003) seem to support KOTEJA's idea.

Comparative investigations of scale insect ovaries (SZKLARZEWICZ \& BILIŃSKI 1995, SZKLARZEWICZ 1997, 1998a, b, c, KOTEJA et al. 2003) have revealed that they exhibit several synapomorphic characters: (a) ovarioles are devoid of terminal filaments, (b) ovarioles contain a small number of germ cells, (c) follicular cells do not diversify into subpopulations. These studies have also shown that ovaries of primitive versus advanced families markedly differ in organization as well as in func-

*Supported by research grant BW/IZ/23b/2004. 

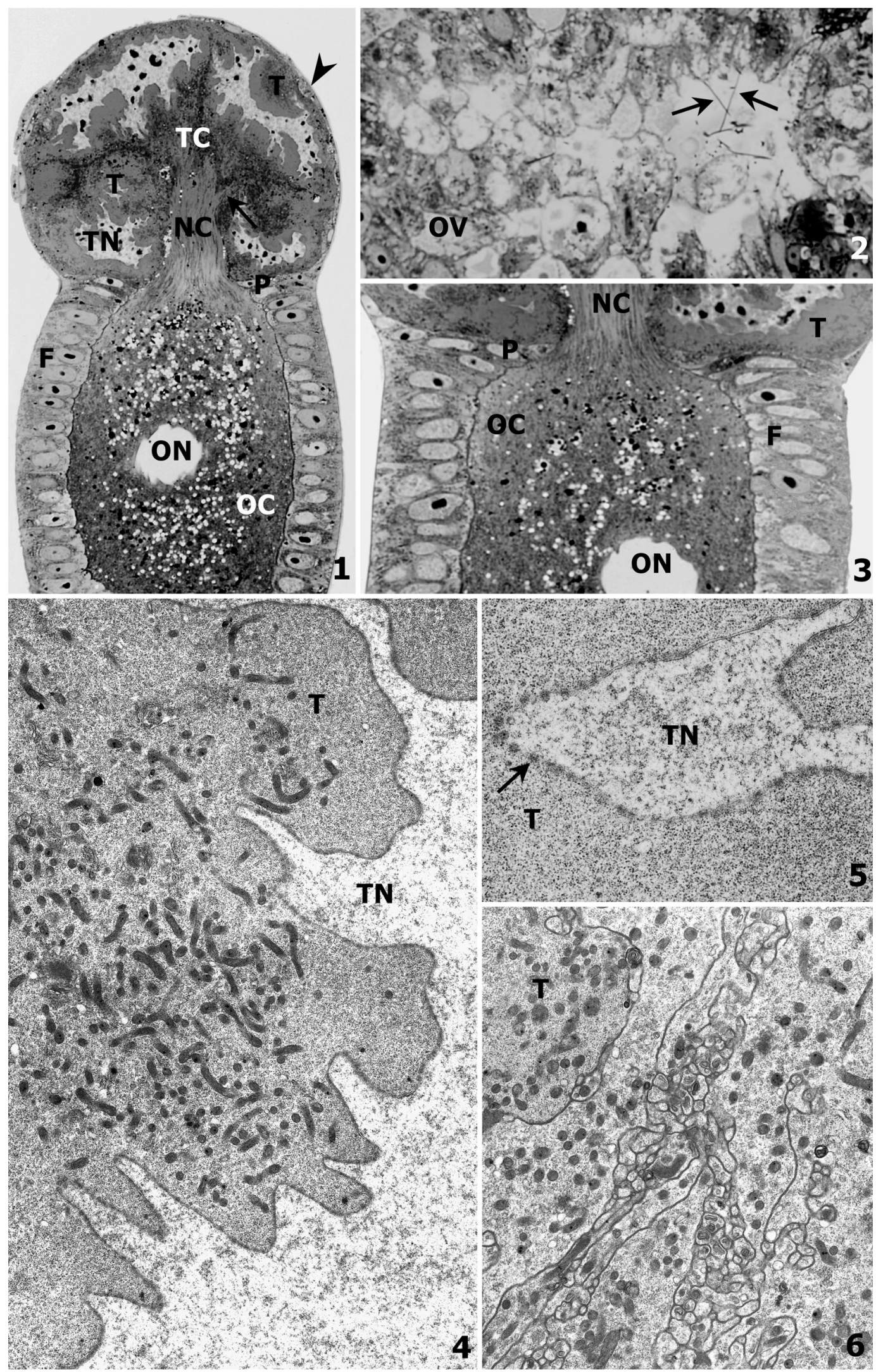

Fig. 1. Longutudinal section through the early vitellogenic ovariole. Arrow - process of trophocyte that joins it to the trophic core, arrowhead - cell of the inner epithelial sheath, $\mathrm{F}$ - follicular epithelium, $\mathrm{NC}$ - nutritive cord, $\mathrm{OC}$ - oocyte, $\mathrm{ON}$ - oocye nucleus, $\mathrm{P}$ - prefollicular cells, T - trophocyte, TC - trophic core, TN - trophocyte nucleus. LM, methylene blue, x 430. Fig. 2. Cross section through the lateral oviduct (OV). Arrows indicate sperm cells in the oviduct lumen. LM, methylene blue, $\mathrm{x} 1$ 000 . Fig. 3. Fragment of the ovariole. $\mathrm{F}$ - follicular epithelium, $\mathrm{NC}-$ nutritive cord, $\mathrm{OC}-$ oocyte, ON - oocyte nucleus, $\mathrm{P}-$ prefolicular cells, T - trophocyte. LM, methylene blue, x 730. Figs 4, 5. Fragment of trophocyte cytoplasm (T) and nucleus (TN). Note numerous pores perforated the nuclear envelope (arrow). TEM, Fig. 4, x 7 300, Fig. 5, x 13 450. Fig. 6. Fragment of the trophic core. Note intertwinned projections of trophocyte membranes. T-trophocyte. TEM, x 9350. 

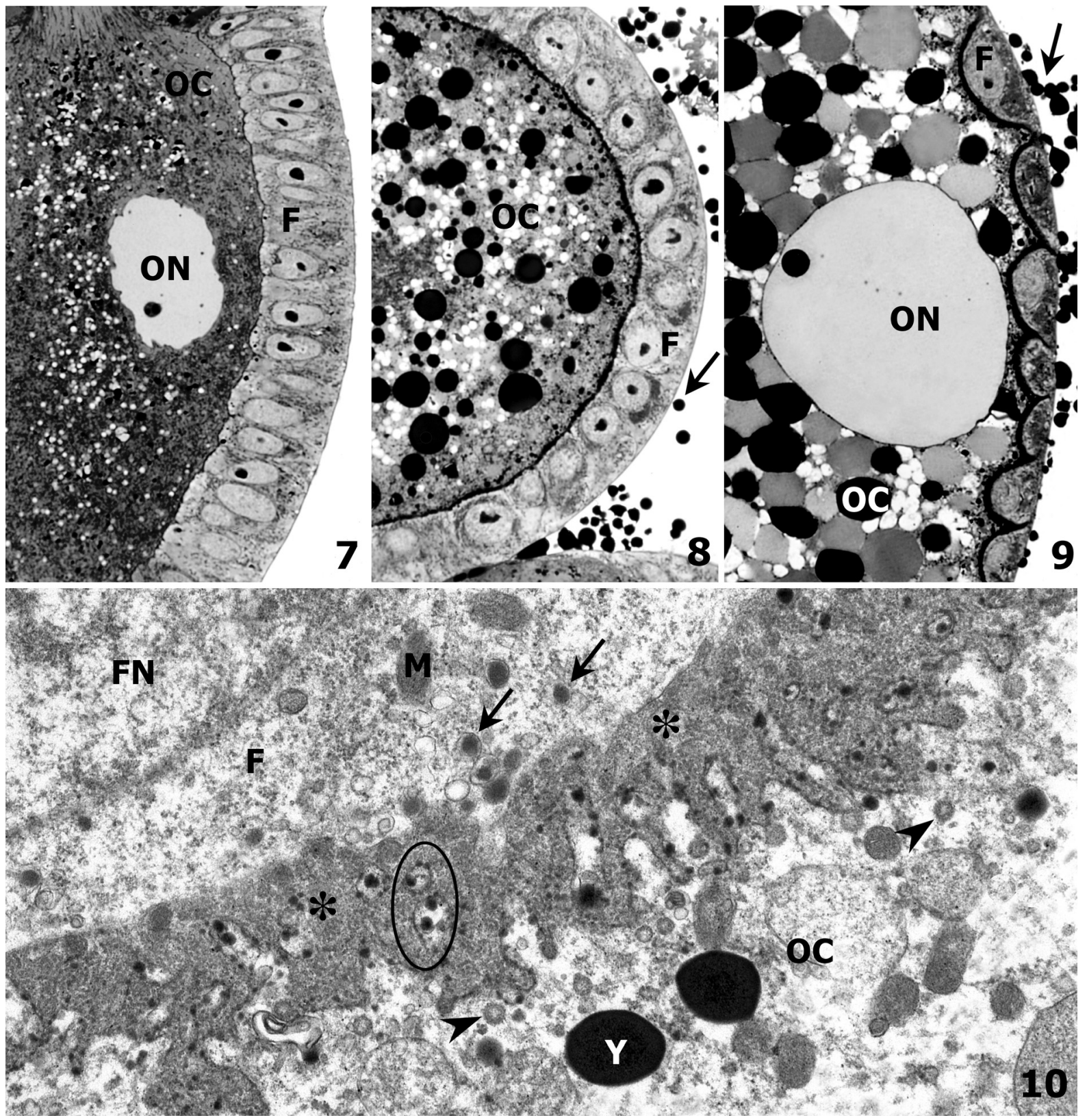

Figs 7-9. Fragment of the oocyte. Fig. 7. Early vitellogenesis. Fig. 8. Mid-vitellogenesis. Fig. 9. Choriogenesis. Arrows endosymbiotic microorganisms, F-follicular cells, OC-oocyte, ON-oocyte nucleus. LM, Fig. 7, x 680, Fig. 8, x 680, Fig. 9 , $x$ 680. Fig. 10. Fragment of the oocyte (OC) and follicular cell (F). Arrows - vacuoles containing precursors of egg envelopes, arrowheads - endocytotic vesicles, asterisk - perivitelline space, encircled - processes of oolemma containing electron-dense granules. FN - folicular cell nucleus, M - mitochondrium, Y - yolk granule. TEM, x 21000.

tion. The major differences pertain to the structure of the tropharia. In the primitive families Ortheziidae, Steingeliidae and Margarodidae s. str. and two advanced families Kermesidae and Eriococcidae, tropharia contain trophocytes and arrested oocytes, whereas in the remaining Neococcoidea only trophocytes are present. Arrested oocytes in Archaeococcoidea are capable of further development, while in Neococcoidea they degenerate. Apart from these dissimilarities, ovaries of scale insects share significant differences in the number of germ cells (trophocytes and oocytes) constituting the ovarioles. Based on these findings SZKLA-
RZEWICZ (1998 c) postulated that: (a) a gradual reduction in number of germ cells per ovariole took place during the evolution of scale insects, (b) ovaries of primitive scale insects are more similar to those of aphids than to advanced ones.

Recently, KOTEJA and co-workers (2003) examined ovaries of Steingelia gorodetskia, a member of the primitive family Steingeliidae, and revealed several considerable differences in the ovary organization between this species and Porphyrophora polonica (Margarodidae s.str.). According to these authors the plesiomorphic features of the ovary as well as advanced external characters (e. 
g., reduction of antennae, eyes, legs, lack of setae) indicate that Steingeliidae are an old group that separated from the main scale insect lineage at a very early time.

The present study was undertaken to provide information about ovary structure in Palaeococcus fuscipennis, a member of the family Monophlebidae that is considered as the most primitive within the Margarodidae s. l. (KOTEJA 1974a, DANZIG 1986). The ovaries of monophlebids have not been thoroughly examined. There are few published informations concerning the chromosome system and ovariole ultrastructure in a hermaphrodite Icerya (HUGHES-SCHRADER 1927, ROYER 1970, NIŻNIK \& SZKLARZEWICZ 2004). It is known that ovarioles of Icerya are composed of 8 germ cells ( 7 trophocytes +1 oocyte). Thus, their organization is atypical within archaecoccoids. It is not unlikely, however, that this character may be an autapomorphy connected with hermaphroditism.

Since numerous studies on ovaries of several groups of insects have revealed that these organs possess very helpful characters for phylogenetic considerations (ŠTYYS \& BILIŃSKI 1990, BILIŃSKI et al. 1998, JAGLARZ 1998, KUBRAKIEWICZ et al. 1998a, KUBRAKIEWICZ et al. 1998b, SIMICZYJEW et al. 1998, SZKLARZEWICZ 1998c, SZKLARZEWICZ et al. 2000, SIMICZYJEW 2002, KOTEJA et al. 2003), we hope that investigations of ovaries of Palaeococcus will contribute to a better understanding of evolutionary trends within Archaeococcoidea.

\section{Material and Methods}

Adult females of Palaeococcus fuscipennis (Burmeister) were collected from the trunks of Pinus sp. in April 2004 in Adana (Turkey). Ovaries were fixed in $2.5 \%$ glutaraldehyde in $0.1 \mathrm{M}$ phosphate buffer ( $\mathrm{pH}$ 7.4) for 3 months. Ovaries were then rinsed in $0.1 \mathrm{M}$ phosphate buffer $(\mathrm{pH}$ 7.4) with the addition of sucrose, posfixed for 1.5 $\mathrm{hr}$ in $1 \%$ osmium tetroxide, dehydrated in a series of alkohol and acetone. The material was next embedded in epoxy resin Epox 812 (Fullam Inc., Latham, NY, USA). Semithin sections were stained with $1 \%$ methylene blue in $1 \%$ borax and photographed under a Jenalumar (Zeiss Jena) microscope. Ultrathin sections were stained with lead citrate and uranyl acetate and examined using a JEM 100 SX EM at $80 \mathrm{kV}$.

\section{Results}

Gross morphology of the ovary

The paired ovaries of Palaecoccus fuscipennis are composed of about 100 short ovarioles of the telotrophic type which are devoid of terminal filaments (Fig. 1) and extend radially from the lateral oviducts. In the oviduct lumen numerous sperm cells are present (Fig. 2). Ovarioles develop asynchronously. The individual ovariole consists of an anterior tropharium and a posterior vitellarium (Fig. 1). A single oocyte develops in the vitellarium (Fig. 1). All germ cells in the ovariole are interconnected and belong to one cluster.

\section{The tropharium}

The tropharia of P. fuscipennis are spherical and comprise large trophocytes and small prefollicular cells (Figs 1,3). The latter are located at the basal part of the tropharium (Figs 1,3). Analysis of serial sections of 10 ovarioles dissected from 10 specimens indicated that tropharia enclose 7 trophocytes. Trophocytes contain large lobated nuclei (Figs 1, 3, 4). The nuclear envelope is abundantly perforated (Fig. 5). The trophocyte cytoplasm is packed mainly with ribosomes and mitochondria (Fig. 4). The centre of the tropharium, termed the trophic core, is devoid of cells (Fig. 1). This region is filled with microtubules (not shown), ribosomes and mitochondria (Fig. 6). Trophocyte membranes that are in the contact with the core form intertwinned projections (Fig. 6). The trophic core is connected both with trophocytes as well as with the oocyte in the vitellarium. Trophocytes communicate with the core by means of long cytoplasmic processes (Fig. 1), whereas oocytes by nutritive cords (Figs 1,3). The trophic chamber is surrounded by flattened cells forming an inner epithelial sheath (Fig. 1).

\section{The vitellarium}

The syntheses of RNA reserve substances (during vitellogenesis) and egg envelopes (during choriogenesis) take place in the vitellarium. The growing oocyte is surrounded with a one-layered follicular epithelium (Figs 1, 7-9). At the onset of vitellogenesis, the oocyte starts to accumulate reserve substances - yolk granules and lipid droplets. The yolk precursors are internalized into the ooplasm via endocytosis (Fig. 10). Follicular cells do not undergo diversification into subpopulations (Figs 1, 3, 7-9). At the beginning of oocyte growth (i.e., previtellogenesis and early vitellogenesis) follicular cells are cylindrical (Fig. 1, 3, 7), during 
advanced vitellogenesis they transform into cubes (Fig. 8), whereas in choriogenesis they become hemisphaeres and their apical parts penetrate the ooplasm (Fig. 9). At the onset of choriogenesis, follicular cells start to synthesize precursors of egg envelopes that via exocytosis are released into perivitelline space (=space between follicular epithelium and the oocyte surface) (Fig. 10). In consequence, the perivitelline space becomes filled with flocculent material (Fig. 10) that corresponds to the internal layer of the egg capsule termed the vitelline envelope.

Oolemma of choriogenic oocytes form short, broad processes directed into perivitelline space (Fig. 10). Electron-dense granules are present in the processes (Fig. 10). The origin, function and contents of these granules are unknown.

In close vicinity to the older ovarioles (i.e., containing oocytes in the vitellogenic or choriogenic stage) numerous endosymbiotic microorganisms are present (Figs 8, 9).

\section{Discussion}

The present study has shown that ovaries of $\mathrm{Pa}$ laeococcus fuscipennis bear features typical of scale insects such as the absence of terminal filaments in ovarioles, a small number of germ cells in ovarioles and undiversified follicular cells. The lack of terminal filaments is a consequence of a unique mode of formation of ovarioles. In scale insects clusters of germ cells (= ovariole anlagen) protrude from the ovary interior into the body cavity (WĘGLARSKA 1961, SZKLARZEWICZ 1997), whereas in the all remaining pterygotous insects ovarioles develop inside the ovary (BÜNING, 1994). Like in the majority of scale insects (SZKLARZEWICZ 1998c, KOTEJA et al. 2003), ovaries of $P$. fuscipennis are composed of numerous ovarioles that contain a small number of germ cells. In each ovariole only a single oocyte develops. Such an organization of the ovary represents most probably an adaptation to parasitism, because it enables the laying of a large number of eggs during a short period. The small number of germ cells is a result of processes of reduction which are characteristic in the evolution of scale insects (see Introduction) and concern not only ovaries but also other organs (e.g., mouthparts, sense organs) (KOTEJA 1974 a, 1980, ROŚCISZEWSKA 1992, SZKLARZEWICZ 1998 c). Since the process of diversification of follicular cells does not occur, egg envelopes of P. fuscipennis are devoid of regional specializations such as micropyle, aeropyle, respiratory appendices, attachment structures (VOGELGESANG \& SZKLARZEWICZ 2001). VOGELGESANG \& SZKLARZEWICZ (2001) suggested that due to the absence of micropylar openings, sperm cells enter oocytes before egg envelopes are formed. It seems that the presence of sperms in lateral oviducts of $P$. fuscipennis at the time the ovarioles contain vitellogenic oocytes strongly supports this assumption. According to KOTEJA (1990) and VOGELGESANG \& SZKLARZEWICZ (2001), the unusual organization of scale insect egg envelopes is associated with the elaboration of various structures for egg protection (e.g., waxy filaments, waxy ovisacs).

The older ovarioles of $P$. fuscipennis are accompanied by endosymbiotic microorganisms that are transovarially inherited (BUCHNER 1965). The ultrastructure and transovarial transmission of endosymbionts in P. fuscipennis will be described in another paper.

Our studies have also shown that the structure of the ovariole of P. fuscipennis is similar to that of another representative of the monophlebids, Icerya purchasi. Ovarioles in both species exhibit significant characters not reported for other margarodids (Margarodidae $s$. lato) examined thus far: (a) a constant and relatively low number (i.e., 8) of germ cells per ovariole versus a variable and much higher number (e.g., 21-41 in Steingelia gorodetskia, 12-19 in Porphyrophora polonica); (b) the existence of trophocytes only in tropharia versus trophocytes and arrested oocytes in tropharia; (c) the development of a single oocyte in each ovariole versus several oocytes (4-6 in S. gorodetskia, 2 in $P$. polonica). Such different organization and functioning of ovaries in different groups of Archaeococcoidea suggest their paraphyly. On the other hand, these findings support the concept of KotejA (1974 a, b) that the Margarodidae s.l. should be divided into several families.

It should be added that ovary organization in the examined monophlebids (P. fuscipennis and I. purchasi) appears to be more similar to ovaries of members of the advanced family Pseudococcidae (SZKLARZEWICZ 1998 a), than to ovaries in other archaeococcoids, namely, Ortheziidae, Margarodidae s. str., Steingeliidae (SZKLARZEWICZ \& BILIŃSKI 1995, SZKLARZEWICZ 1997, 1998 a, KOTEJA et al. 2003). There are two possible explanations of this phenomenon: (a) the family Monophlebidae is not a sister group to Neococcoidea and the similarity may be a result of homoplasy, (b) the family Monophlebidae is a sister group to Neococcoidea and the similarity may represent a synapomorphy of Monophlebidae and Neococcoidea. However, to verify these hypotheses further studies on ovaries as well as on the remaining organs in other members of Margarodidae $s$. $l$. are required. 


\section{Acknowledgemens}

The authors are grateful to Dr. Penny GuLLAN (University California Davis) for her valuable suggestions and Dr. Beata SZYMAŃSKA and M.Sc. Władysława JANKOWSKA for their skilled technical assistance.

\section{References}

BILIŃSKI S. M., BÜNING J., SIMICZYJEW B. 1998. The ovaries of Mecoptera: basic similarities and one exception to the rule. Folia Histochem. Cytobiol. 36: 189-196.

BORCHSENIUS N. 1956. The question of the course of evolution of Coccoidea (Insecta, Homoptera). Zool. Zhur. 35 546-553. (In Russian).

BUCHNER P. 1965. Endosymbiosis of animals with plant microorganisms. John Wiley \& Sons Interscience, New York.

BÜNING J. 1994. The ovary of Ectognatha, the insects s. str. (In: The Insect Ovary. Ultrastructure, Previtellogenic Growth and Evolution. J. Büning ed., Chapmann \& Hall, London): 40-58.

CoOK L. G., Gullan P. J., TRueman H. E. 2002. A preliminary phylogeny of the scale insects (Hemiptera: Sternorrhyncha: Coccoidea) based on nuclear small-subunit ribosomal DNA. Mol. Phyl. Evol. 25: 43-52.

DANZIG E. M. 1986. Coccids of the Far-Eastern USSR (Homoptera, Coccinea), with phylogenetic analysis of coccids in the world fauna. Amerind Publishing, New Delhi.

FOLDI I. 1997. Defense strategies in scale insects: Phylogenetic inference and ewolutionary scenarios (Hemiptera Coccoidea). (In: The Origin and Biodiversity in Insects: Phylogenetic Tests of Evolutionary Scenarios. Mem. Mus. Natn. Hist. Nat. P. Grandcolas ed., ISBN, Paris) 173: 203-230.

GULlan P. J., SJAARDA W. 2001. Trans-Tasman Platycoelostoma Morrison (Hemiptera: Coccoidea: Margarodidae) on endemic Cupressaceae, and the phylogenetic history of margarodids. System. Entomol. 26: 257-278.

HUGHES-SCHRADER S. 1927. Origin and differentiation of the male and female germ cells in the hermaphrodite of Icerya purchasi (Coccidae). Z. Zellforsch. 6: 509-540.

JAGLARZ M. K. 1998. The number that counts. Phylogenetic implications of the number of nurse cells in ovarian follicles of Coleoptera-Adephaga. Folia Histochem. Cytobiol. 36: 167-178.

KOTEJA J. 1974a. On the phylogeny and classification of the scale insects (Homoptera, Coccinea) (discussion based on the morphology of the mouthparts). Acta zool. crac. 14 267-325.

KotejA J. 1974b. Compararative studies on the labium in the Coccinea (Homoptera). Zeszyty Naukowe AR Kraków, Rozprawy 27: 1-162.

KoteJA J. 1980. Campaniform, basiconic, coeloconic, and intersegmental sensilla on the antennae in the Coccinea (Homoptera). Acta biol. crac., Ser. Zool. 22: 73-88.

KotEJA J. 1990. Developmental biology and physiology. (In: Armored scale insects. Their Biology, Natural Enemies and Control. World Crop Pests. D. Rosen ed., Elsevier, Amsterdam): 233-242.

KOTEJA J., PYKA-FOŚCIAK G., VOGELGESANG M., SZKLARZEWICZ T. 2003. Structure of the ovary in Steingelia (Sternorryncha:
Coccinea), and its phylogenetic implications. Arthropod Struct. Dev. 32: 247-256.

KUBRAKIEWICZ J., BILIŃSKi S. M., MAZURKIEWICZ M. 1998a. Diptera - ovary structure and oogenesis. Folia Histochem. Cytobiol. 36: 197-203.

KUBRAKIEWICZ J., JEDRZEJOWSKA I., BILIŃSKI S. M. 1998b. Neuropteroidea - different ovary structure in related groups. Folia Histochem. Cytobiol. 36: 179-188.

MiLLER D. R. 1984. Phyllogeny and classification of the Margarodidae abd related groups (Homoptera: Coccoidea). Proc. Int. Symposium of Central European Entomofaunistics 10: 321-324.

MORRISON H. 1928. A classification of the higher groups and genera of the coccid family Margarodidae. US Dept. Agr. Washington Tech. Bull. 52: 1-237.

NiŻNIK S., SzKLARZEWICZ T. 2004. Structure and development of the hermaphrodite gonad in the cottony cushion scale, Icerya purchasi (Insecta, Hemiptera, Coccinea: Monophlebidae). Acta biol. crac., Ser. Bot. XXVI Conf. Embryol., Abstracts, 46: 41.

RoŚCISZEWSKA M. 1992. Antennae of female Orthezioidea (Homoptera, Coccinea): Morphology of sense organs. Zool. Jb. Abt. Anat. 122: 343-359.

ROYER M.M. 1970. Observations sur l'ultrastucture de l'ovariole d'Icerya purchasi Mask. (Insecte, Homoptere, Coccide). C.R. Acad. Sci. Paris 270: 3246-3249.

SIMICZYJEW B. 2002. Structure of the ovary in Nannochorista neotropica Navas (Insecta: Mecoptera: Nannochoristidae) with remarks on mecopteran phylogeny. Acta zool. (Stockholm) 83: 61-66.

SiMICZYJEW B., OGORZAŁEK A., ŠTYS P. 1998. Heteropteran ovaries: variations on the theme. Folia Histochem. Cytobiol. 36: $147-156$

SZKLARZEWICZ T. 1997. Structure and development of the telotrophic ovariole in ensign scale insects (Hemiptera, Coccomorpha: Ortheziidae). Tissue Cell 29: 31-38.

SZKLARZEWICZ T. 1998a. Structure of ovaries of scale insects. I. Pseudococcidae, Kermesidae, Eriococcidae, and Cryptococcidae (Insecta, Hemiptera, Coccinea). Int. J. Insect Morphol. Embryol. 27: 162-172.

SZKLARZEWICZ T. 1998b. Structure of ovaries of scale insects. II. Margarodidae (Insecta, Hemiptera, Coccinea). Int. J. Insect Morphol. Embryol. 27: 319-324.

SZKLARZEWICZ T. 1998c. The ovaries of scale insects (Hemiptera, Coccinea). Morphology and phylogenetic conclusions. Folia Histochem. Cytobiol. 36: 157-165.

SZKLARZEWICZ T., BILIŃSKI S. M. 1995. Structure of ovaries in ensign scale insects, the most primitive representatives of Coccomorpha (Insecta, Hemiptera). J. Morphol. 224: 23-29

SZKLARZEWICZ T., WNĘK A., BILIŃSKI S. M. 2000. Structure of ovarioles in Adelges laricis, a representative of the primitive aphid family Adelgidae. Acta zool. (Stockholm) 81: 307-313.

ŠTYS P., BILIŃSKI S. M. 1990. Ovariole types and the phylogeny of hexapods. Biol. Rev. 65: 401-429.

VOGELGESANG M., SzKLARZEWICZ T. 2001. Formation and structure of egg capsules in scale insects (Hemiptera, Coccinea). I. Ortheziidae. Arthropod Struct. Dev. 30: 63-68.

WEGLARSKA B. 1961. Oogenesis in the ovoviviparous scale insect Quadraspidiotus ostreaeformis Curt. (Homoptera, Coccidae, Aspidiotini). Morphological and cytological investigations. Zool. Pol. 11: 267-294. 